ROCZNIKI TEOLOGICZNE

Tom LXVI, zeszyt 1 - 2019

DOI:http://dx.doi.org/10.18290/rt.2019.66.1-3

\author{
KS. WITOLD JANOCHA \\ ANNA OLESIŃSKA
}

\title{
FEMINIZACJA UBÓSTWA I STRATEGIE RADZENIA SOBIE Z BIEDA NA PRZYKŁADZIE MIESZKANEK LUBLINA
}

\author{
FEMINIZATION OF POVERTY AND POVERTY COPING STRATEGIES \\ ON THE EXAMPLE OF THE INHABITANTS OF LUBLIN
}

\begin{abstract}
A b s t r a c t. Feminization of poverty is still an issue of current and demanding in-depth research. The lower level of women's remuneration in relation to men, unpaid and underestimated work in the household, raising children, consequently, low or lack of pension benefits, all this means that women are more vulnerable to poverty than men. Conducted by the authors of the article, the study shows the high activity of women in a situation of poverty. Most respondents use all available opportunities to minimize expenditures, maximize revenues and improve the family's economic situation. The results of the research show a picture of active and resourceful women who put in a lot of effort to satisfy the basic needs of the family. This is in contradiction with the stereotypical perception of poor people, as a lazy, not involved in their own affairs, waiting only for institutional help.
\end{abstract}

Key words: poverty; feminization of poverty; strategies for coping with poverty.

Problem ubóstwa kobiet w niewielkim stopniu jest zauważany przez politykę społeczną. Zwracają uwagę dysproporcje w wynagrodzeniach kobiet i mężczyzn, ograniczony dostęp do wyższych stanowisk, nieodpłatna i niezauważalna praca w domu oraz wychowywanie dzieci, korzystanie z urlopów wychowawczych, to wszystko wpływa także na wysokość świadczeń emery-

Ks. dr hab. WITOLD JANOCHA, prof. KUL - Instytut Nauk o Rodzinie i Pracy Socjalnej KUL; adres do korespondencji - e-mail: wjanocha@kul.pl ANNA OLESINSSKA - absolwentka studiów: Praca socjalna (KUL). 
talnych, które często są na najniższym poziomie. W szczególnie trudnej sytuacji znajdują się kobiety samotne, wychowujące dzieci, ponieważ w większości ich dochody są bardzo niskie, w konsekwencji dzielą biedę wraz ze swoimi dziećmi. Wymienione elementy powodują, że kobiety należą do grupy osób zagrożonych ubóstwem w okresie całego życia. Badania naukowe nad feminizacją ubóstwa wskazują na duże obciążenie kobiet, które w sytuacji biedy stają się jej menadżerkami. Poświęcają czas, energię, podejmując liczne działania ograniczające skutki biedy dla swoich rodzin.

W niniejszym artykule poruszone zostaną zagadnienia feminizacji ubóstwa, strategii, jakie przyjmuja kobiety, aby minimalizować skutki ubóstwa oraz zaprezentowane zostaną badania własne, które zostały przeprowadzone na wybranej grupie mieszkanek Lublina.

\section{FEMINIZACJA UBÓSTWA - ZDEFINIOWANIE POJĘĆ}

Termin „feminizacja ubóstwa” zastosowany został po raz pierwszy w 1978 roku, $\mathrm{w}$ artykule D. Pearce The feminization of poverty: women, work, and welfare. Autorka zwracała uwagę między innymi na trudną sytuację kobiet związaną z rynkiem pracy. Ponownie powrócono do tego tematu $\mathrm{w}$ drugiej połowie lat 90., gdy na konferencji w Stanach Zjednoczonych przedstawiono statystyki dotyczące odsetka kobiet wśród ubogich na świecie. Według przedstawionych badań kobiety stanowiły $70 \%$ ogółu liczby osób żyjących w ubóstwie. Dopiero publikacja tych wyników badań przyczyniła się do tego, że problematykę tę uznano za ważny obszar badań ${ }^{1}$.

Feminizacja ubóstwa jest procesem, dlatego należy ją analizować na przestrzeni lat. Można o niej mówić wówczas, gdy wskaźniki ubóstwa wśród kobiet są większe niż wśród mężczyzn. Podobnie jak w przypadku samego ubóstwa nie ma jednoznacznej definicji feminizacji ubóstwa. W literaturze przedmiotu spotykamy trzy podejścia do definicji: ilościowe, jakościowe oraz mieszane.

Definicje pierwszego typu wykorzystują wskaźniki ilościowe: udział kobiet wśród ubogich, zasięg i głębokość ubóstwa kobiet wobec analogicznych wskaźników wśród mężczyzn. Przykładem podejścia ilościowego jest definicja D. Pearce: „Wzrost liczby kobiet wśród ogółu ubogich oraz wzrost liczby gospo-

\footnotetext{
${ }^{1}$ E. NASSALSKA, Ocena instrumentów stosowanych $w$ walce z ubóstwem $w$ opinii ubogich kobiet $w$ Polsce, Wrocław 2011, s. 64.
} 
darstw ubogich kierowanych przez kobiety wśród ogółu gospodarstw ubogich"2. Definicje jakościowe określają feminizację ubóstwa ze względu na specyficzne konsekwencje spowodowane biedą wśród kobiet. Istotne są różnice w doświadczaniu biedy w zależności od płci. W badaniach bierze się pod uwagę zróżnicowany stopień zagrożenia głodem, zakres obowiązków i działania podejmowane przez kobiety i mężczyzn. Według I. Reszke, feminizacja ubóstwa to: „Konsekwencje biedy dotkliwsze dla kobiet niż mężczyzn, na przykład podjęcie przez nie odpowiedzialności za utrzymanie i przetrwanie rodziny (starania o zasiłki, zapomogi, o pomoc organizacji charytatywnych, zaciąganie pożyczek, kupowanie na kredyt) i większe obciążenie obowiązkami w gospodarstwie domowym w warunkach ubóstwa niż w sytuacji zamożności"’3.

W Polsce dominują definicje mieszane. Definicja E. Tarkowskiej określa feminizację ubóstwa jako „liczbową przewagę kobiet wśród osób żyjących poniżej linii ubóstwa oraz szczególne obciążenie kobiet trudną sytuacją ekonomiczną rodziny i podejmowanymi wysiłkami w celu zaspokojenia podstawowych potrzeb jej członków"4. Definicja ta obejmuje wskaźniki ilościowe oraz jakościowe, które pozwalają na szerokie objęcie zjawiska. Badania nad feminizacją ubóstwa w Polsce są utrudnione, ponieważ statystyki poziomu ubóstwa nie pokazują dochodu przypadającego na poszczególnych członków rodziny a obejmuja gospodarstwo domowe jako całość.

M. Medeiros i J. Costa zwracają uwagę, że badania powinny dotyczyć nierówności wewnątrz gospodarstw domowych i dysproporcji w podziale dochodu miedzy kobietę a mężczyznę. Gospodarstwo domowe, traktowane jako całość, może odwracać uwagę od istotnych czynników ubóstwa wśród kobiet $^{5}$. Jest to ważne, ponieważ otrzymane wyniki pokazują, że kobiety są bardziej zagrożone ubóstwem niż mężczyźni, a skutki społecznego zaniedbania w dzieciństwie mają większe konsekwencje dla kobiet niż mężczyzn. Dotyka to szczególnie samotne matki, emerytki i kobiety opiekujące się osobami zależnymi i spycha na dalszy plan ubóstwo kobiet w rodzinach, w których podział dochodu jest nierównomierny, a potrzeby żony i matki są realizowane na samym końcu. Taki typ ubóstwa ukrytego wymyka się statystykom. Brytyjskie badania wykazały, że „ortodoksyjny model gospodarstwa domowego jako pewnego bytu egalitarnego pod względem podejmowania

\footnotetext{
2 Tamże, s. 65.

${ }^{3}$ E. NASSAlsKa, Ocena, s. 66.

${ }^{4}$ Tamże, s. 66.

${ }^{5}$ Tamże, s. 67.
} 
decyzji, gdzie zasoby dzielono równo, można zastosować jedynie do 1/5 badanych przypadków" "Żony mają do dyspozycji mniejsze środki finansowe niż mężowie i zróżnicowany jest dostęp do pieniędzy na własne wydatki. Innym aspektem ukrytego ubóstwa jest zależność finansowa kobiet i władza mężczyzn oraz poświęcanie się na rzecz dzieci i innych członków rodziny.

Różnice w podziale dóbr w ramach rodziny są spowodowane rozdźwiękiem między realnym a postrzeganym wkładem w dochód rodziny. Aktywność kobiet, która nie jest uznana społecznie i prawnie, nie jest brana pod uwage jako kryterium podziału. Postrzeganie korzyści i wkładu zależy od wartości, jaką osoba przypisuje własnemu dobrobytowi czy swojej pracy. Wpływ ma także niewidoczność pracy wykonywanej w domu, liczba dzieci, czy podział prac w gospodarstwie domowym. Zależność ekonomiczna w rodzinie zmniejsza wiarę osoby w swoje zdolności i nie pozwala myśleć o zmianie ${ }^{7}$.

Kolejny element feminizacji ubóstwa to: „poświęcanie się”. Zjawisko znane od wieków, niezależnie od kultury. W dziewiętnastowiecznej Polsce twórczość Elizy Orzeszkowej wielokrotnie opisywała kobietę-matkę, która była „samotna, wiecznie czymś zmartwiona, ale też heroiczna, pracowita i całym sercem oddana swoim dzieciom, gotowa do wielu poświęceń"8. Kobiety chronią członków swojej rodziny przed skutkami biedy, radząc sobie z długami, poszukując oszczędności, biorąc na siebie kontakty z instytucjami pomocowymi. Często rezygnują ze swoich niezbędnych wydatków na rzecz innych członków rodziny. Stres i jego niszczący wpływ na zdrowie fizyczne i psychiczne jest często konsekwencją zmagania się z trudną codziennością.

Inny aspekt działań kobiet to poświęcanie czasu, aby zaoszczędzić pieniądze. Nakład czasu, jaki kobieta w sytuacji ubóstwa poświęca na codzienną pracę w domu, jest często pomijany i niedoceniany, „bo czas ludzi ubogich jest traktowany jako bezwartościowy" ". Jest to czas poświęcony na robienie tanich zakupów w sklepach lub bazarach znacznie od siebie oddalonych, przygotowywanie pracochłonnych posiłków z nieprzetworzonych produktów, prace domowe, które mają nieraz na celu ukrycie niedostatku i zwiększenie poziomu życia innych członków rodziny. Poruszanie się z wyboru tańszym

${ }^{6}$ R. LISTER, Bieda, Warszawa 2007, s. 74-75.

${ }^{7}$ D. Zwarthoed, Zrozumieć biedę. John Rawls - Amartya Sen, Warszawa 2012, s. 111 114.

8 J. JAŚKIEWICZ, Kobieta-matka w wybranych tekstach publicystycznych Elizy Orzeszkowej, w: Acta Universitatis Lodziensis, Folia Litteraria Polonica, 13, 2010, s. 141, file:///C:/Users/Downloads/Joanna\%20Ja\%20kiewicz.pdf (dostęp: 09.04.2018).

${ }^{9}$ R. LISTER, Bieda, s. 78. 
transportem publicznym wymagającym dłuższego czekania na przystankach, albo pieszo. Kobieta może być biedniejsza nie tylko ekonomicznie, w kategoriach możliwości i konsumpcji, ale może być uboższa w czas i energię, jaka jej zostaje po zaspokojeniu potrzeb innych. Podejmowano próby włączenia czasu i wycenę nierynkowego czasu pracy do pomiaru biedy, ale ze względu na złożoność zjawiska próby te są bardzo rzadkie. W światowych badaniach wprowadzono jednak pojęcie ,,satelickich kont gospodarstw domowych”, mierzących i określających nieodpłatną pracę na rzecz domu ${ }^{10}$.

Praca w domu jest wiązana $\mathrm{z}$ realizacją naturalnej roli, jaką pełni kobieta. Stwierdzenie, że kobieta zajmująca się domem nie pracuje, ma uzasadnienie w marksistowskiej teorii wartości i podziale pracy na produkcyjną i nieprodukcyjną. Gospodarstwo domowe nie generuje dochodu, nie jest przedsiębiorstwem i praca w nim nie może być traktowana jako praca ${ }^{11}$. W Polsce zagrożone ubóstwem są kobiety będące głównymi żywicielami rodziny i nie dotyczy to tylko samotnych matek. Do tej grupy należą także emerytki i kobiety mające pod opieką osoby zależne: dzieci i dorosłe osoby z niepełnosprawnością czy starszych rodziców.

\section{KLASYFIKACJE STRATEGII RADZENIA SOBIE Z BIEDĄ}

Zarządzanie biedą może być ujmowane w kategoriach strategii. Jedną spośród wielu klasyfikacji jest ta - opracowana przez S. Gilliata - z podziałem na: pomnażanie dochodów, minimalizację wydatków i zarządzanie stre$\mathrm{sem}^{12}$. Aktywne strategie maksymalizacji dochodów obejmuja podejmowanie dodatkowej pracy w kraju i za granicą, także na czarno oraz pracy w nadgodzinach. Wykorzystywanie umiejętności krawieckich, szydełkowania do produkcji rzeczy na sprzedaż, gotowanie na przyjęciach, wykonywanie za opłatą drobnych usług remontowych sąsiadom. Charakterystycznym rodzajem jest podejmowanie pracy sezonowej przez dzieci i młodzież w czasie wakacji i roku szkolnego. Zbieranie truskawek, pilnowanie dzieci sąsiadom, zbieranie ślimaków to często podejmowane zarobkowe zajęcia ${ }^{13}$. Strategie maksymali-

\footnotetext{
10 Tamże, s. 79.

11 A. Titkow, D. Duch-KrzYszToszeK, B. BudrowskA, Nieodptatna praca kobiet. Mity, realia, perspektywy, Warszawa 2014, s. 10.

${ }^{12}$ R. LISTER, Bieda, s. 164.

${ }^{13}$ E. TARKOWSKA, O strategiach radzenia sobie z bieda, w: Ubóstwo, bezrobocie, bezdomność. Działania profilaktyczne, pomocowe, red. M. Mikołajczyk, Warszawa 2015, s. 39.
} 
zacji dochodów, minimalizacji potrzeb i wydatków, podejmowane przez osoby biedne, zwracają uwagę na ich sprawczość i aktywność. Przełamują do pewnego stopnia myślenie o całej grupie ubogich jako bezradnych, roszczeniowych i biernych. W biednych rodzinach to kobiety przejmują odpowiedzialność za planowanie budżetu. Lawirują między potrzebami a możliwościami, stając się „menadżerkami biedy”. Planowanie, ,kombinowanie” i kontakty z instytucjami pomocy społecznej wymagają dużego nakładu czasu i wysiłku. Godna podziwu zaradność kobiet obciążona jest dużym ciężarem psychicznym, który ponoszą mierząc się z poczuciem zniechęcenia i bezsilności ${ }^{14}$. Niski dochód wymaga podjęcia różnorodnych działań, które pozwolą zminimalizować braki w budżecie domowym. Trudności w związaniu końca z końcem powodują zróżnicowane reakcje: ofensywne, nastawione na działanie, skierowane na aktywne poszukiwanie dodatkowych źródeł dochodu, albo bardziej defensywne, nastawione na szukanie oszczędności przez ograniczanie potrzeb.

Strategie oszczędnościowe obejmują redukcję albo całkowitą rezygnację z nawet najpilniejszych wydatków na żywność, ubrania, leki, opłaty za mieszkanie, wizyty u lekarza, transport, ogrzewanie, edukację oraz życie towarzyskie. Sposobem oszczędzania są zakupy w dyskontach w czasie promocji, na bazarach oraz sklepach $\mathrm{z}$ tanią odzieżą $\mathrm{w}$ dniach gdy towar jest za złotówkę. Wymaga to nakładu czasu i pokazywania większych odległości w celu skorzystania z promocji. Często nabywane produkty są gorszej jakości. W rejonach wiejskich stosuje się sezonowe zbieractwo jagód czy grzybów, które stają się podstawą do przygotowania tanich posiłków. Nadwyżki są marynowane lub przeznaczone na sprzedaż. Powszechne jest przygotowywanie posiłków „z niczego”, do których wykorzystywane są kości i korpusy zamiast mięsa. Przedłuża się działanie przedmiotów przez wielokrotne naprawy robione we własnym zakresie. Osoby ubogie stosują ograniczenia w użyciu bieżącej wody podczas zmywania, restrykcyjnie pilnuje się gaszenia światła, przykręca kaloryfery w pomieszczeniach, telefon służy tylko do odbierania wiadomości. W pierwszej kolejności rezygnuje się z kina, rozrywki, spotkań towarzyskich. Potrzebne leki są zastępowane domowymi sposobami leczenia, albo zamieniane są na tańsze odpowiedniki.

Stres w sytuacji ubóstwa związany jest z subiektywnymi odczuciami, jakie towarzyszą biednym na co dzień, z poczuciem jak są odbierani przez osoby nie doświadczające biedy, co o biednych się mówi i myśli, jak przeżywają

\footnotetext{
${ }^{14}$ R. LISTER, Bieda, s. 167.
} 
swoją codzienność i jak sobie radzą ze wstydem, poczuciem winy, naruszeniem godności i praw obywatelskich. Podejmowanie restrykcyjnych oszczędności, zaciąganie pożyczek i życie z długami powodują poczucie zagrożenia i zmęczenia codziennością. Jest to relacyjno-symboliczny wymiar biedy, który pojawia się $\mathrm{w}$ momencie kontaktu świata biedy z osobami, które biedne nie są. Jest to sfera uczuć i emocji, które należą do najtrudniejszych w doświadczaniu biedy. R. Lister wprowadziła określenie tej relacji, jako traktowanie biednych w kategoriach „Innego”, czyli odmiennych od reszty społeczeństwa. Znaczące jest istnienie symbolicznej linii, która oddziela biednych od niebiednych. Ubodzy znajdujący się po drugiej stronie są stereotypizowani, dzieleni na zasługujących na wsparcie i nie zasługujących, postrzegani jako ci, którzy sami sobie na biedę zasłużyli ${ }^{15}$. Wpływa to na sposób traktowania ubogich przez instytucje pomocowe i społeczeństwo. Według Beckera „biedni [...] najczęściej przedstawiani są jako Inni - albo ponoszący odpowiedzialność za swój los, albo stanowiący bierny przedmiot zainteresowania, któremu odmawia się potencjału sprawczego. W najlepszym razie są oni obiektem litości lub obojętności ze strony „niebiednych”, a w najgorszym - obiektem strachu, pogardy czy wrogości”, ludźmi, „którym trzeba pomóc lub których trzeba ukarać, zignorować lub zbadać, lecz którzy rzadko kiedy traktowani są jako

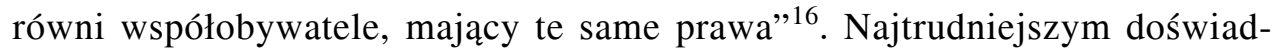
czeniem osób biednych jest odczuwany brak szacunku i uznania ze strony niebiednych. Naruszenie godności i ograniczenie praw obywatelskich w zamian za pomoc, jest najdotkliwiej odczuwanym wymiarem ubóstwa. Niezrozumienie świata biedy jest spowodowane niedopuszczeniem do głosu osób, które doświadczają biedy i najwięcej o niej wiedzą. Programy zwalczania ubóstwa wymagają od biednych bycia gotowymi do podjęcia różnych działań, lekceważą one codzienny wysiłek wkładany w zarządzanie biedą. Wymiar emocjonalny jest najczęściej pomijany. Następny punkt artykułu oddaje głos ubogim kobietom, które jako „menadżerki biedy” zmagają się z trudną codziennością.

\footnotetext{
15 Tamże, s. 126-127.

16 Tamże, s. 144.
} 


\section{METODOLOGIA BADAŃ WŁASNYCH}

Do przeprowadzenia badań strategii radzenia sobie z biedą posłużono się wywiadem swobodnym, ukierunkowanym, tzw. pogłębionym. Wywiady zostały przeprowadzone w oparciu o wcześniej przygotowane pytania. Istotna była dokładność zapisu, wobec tego wykorzystano możliwość zapisu na dyktafon, a następnie $\mathrm{z}$ odsłuchu dokonano zapisu na kartę zapisu. Na potrzeby pracy dokonano celowego doboru próby ${ }^{17}$. Kryterium stanowiła płeć i dochód na osobę w rodzinie. Samo kryterium dochodowe na poziomie minimum socjalnego potraktowano umownie, tzn. wzięto pod uwagę tolerancję w granicach 200 złotych. Granice minimum socjalnego są elementem sztucznego podziału osób na ubogie i nieubogie. Wywiady zostały przeprowadzone od marca do maja 2018 roku w Lublinie na próbie trzynastu kobiet. Podstawowym kryterium doboru respondentek był dochód na poziomie zbliżonym do minimum socjalnego, które wynosi 1.132,21 złotych dla jednoosobowego gospodarstwa emeryckiego i 899,32 złote na pięć osób w rodzinie. Przewidziano tolerancję do 200 złotych na osobę, ponieważ w badaniach wzięto pod uwagę wielowymiarową definicję biedy oraz - zdaniem autorów - kryteria eksperckie nie przystają do rzeczywistości, a koszyki potrzeb i wydatków są zaniżone. Minimum socjalne powinno pozwolić na „utrzymanie więzi społecznych"18 i respondentki te więzi do pewnego stopnia utrzymują, ale nie jest to zasługa dobrze opracowanego koszyka potrzeb, lecz restrykcyjnego planowania budżetu i oszczędności podejmowanych przez kobiety. Badania przeprowadzane $\mathrm{w}$ grupie respondentek, w których kryterium jest np. korzystanie z pomocy społecznej, pomija wiele osób, które doświadczają biedy, a znajdując się poza tym kryterium nie są ujmowane $w$ badaniach oraz stają się niewidzialne dla statystyk i polityki społecznej.

Przeprowadzono 13 wywiadów w zróżnicowanej grupie pod względem wieku, wykształcenia, sytuacji rodzinnej oraz statusu na rynku pracy. Najszerszym kryterium był wiek, ponieważ panie miały od 20 do 82 lat. Wśród badanych trzy były w wieku od 20 do 35 lat, cztery w wieku od 36 do 60 lat, oraz sześć w wieku powyżej 61 roku życia. Respondentki były zróżnicowane pod względem stanu cywilnego: jedna z pań jest niezamężna, cztery są mężatkami, trzy są rozwiedzione, pięć jest wdowami. Respondentki były także

\footnotetext{
${ }^{17}$ E.R. BABBIE, Badania społeczne w praktyce, Warszawa 2003, s. 212.

${ }^{18}$ IPiS, Informacja o poziomie minimum socjalnego w 2017 roku, Warszawa 2018, file:///C:/Users/Komputer/Downloads/MS-2017-1-12-www.pdf, s. 1 (dostęp: 22.05.2018).
} 
grupa zróżnicowaną pod względem statusu na rynku pracy: pięć jest emerytkami, jedna z pań pracuje, dwie pracują i równocześnie studiują, trzy są rencistkami ( $w$ tym jedna studiuje), jedna pani pozostaje w domu, opiekując się dziećmi i jedna studiuje. Pod względem wykształcenia najwięcej, bo siedem pań ma wykształcenie średnie, trzy - wyższe, jedna - podstawowe i dwie - zawodowe. Zróżnicowana jest także liczba dzieci: trzy panie nie mają dzieci, cztery respondentki mają dwójkę dzieci oraz sześć pań ma od 4 do 8 dzieci. Dochód respondentek znajdował się w przedziale od 400 do 1350 złotych na osobę. Dochód jednej z rozmówczyń był mniejszy niż 500 złotych na osobę, sześciu od 600 do 1000 oraz sześciu od 1100 do 1350 złotych. Dwie panie pobieraja świadczenie 500+ i, pomimo że nie jest ono ustawowo doliczane do dochodu, zostało uwzględnione w badaniach w celu urealnienia rzeczywistej sytuacji dochodowej. W opinii respondentek w stosunkowo dobrej sytuacji dochodowej znajdują się te, które mają kilkoro małych dzieci (do 18 roku życia), którym przysługuje świadczenie 500+ (trzeba jednak pamiętać, że świadczenia są zależne od założeń polityki rządu, i na skutek zmian politycznych moga zostać wycofane), inne grupy: młode kobiety bez dzieci, emerytki lub kobiety w średnim wieku (szczególnie samotne lub mające dzieci powyżej 18 roku życia) są w trudniejszej sytuacji materialnej. Wywiady trwały od 40 do 90 minut, w zależności od stopnia otwartości respondentek na poruszane tematy.

\section{STRATEGIE MINIMALIZACJI WYDATKÓW \\ I MAKSYMALIZACJI DOCHODÓW - PREZENTACJA BADAŃ WŁASNYCH}

Każda z respondentek podejmowała działania zmierzające do minimalizacji wydatków. Różnice wypływały z sytuacji osobistej badanych. Dziewięć z nich samodzielnie dysponowało dochodem, cztery ustalały główne wydatki (opłaty, spłata kredytu, kwota przeznaczona na żywność) wspólnie z mężem, a następnie same decydowały co jest konkretnie potrzebne i jakie produkty kupią. Respondentki wyrażały to w następujący sposób: „Ja zapisuję jakie są opłaty w danym miesiącu, ile czego trzeba płacić [...] i wtedy się zastanawiamy, tu brakuje, tu brakuje, to wtedy co trzeba najpilniejsze opłacić i opłacamy, potem co zostaje to jeszcze ewentualnie myślimy co dalej i ile pieniędzy nam starcza, to myślimy w jaki sposób zakupy robić [...] nie starcza na to żeby wszystko opłacić w jednym miesiącu, to wtedy się przesuwa z jednego miesiąca na drugi” (W2); „Dochodem ja dysponuję, on nie chciał, bo jak raz 
spróbował, to mu po dwóch tygodniach zabrakło, a tak krzyczałeś gdzie ja pieniądze podziewam - powiedziałam" (W7).

Jedna z pań, młoda mężatka, oddała zarządzanie dochodem mężowi, ponieważ w sytuacji poważnych braków samodzielne planowanie wydatków było dla niej zbyt obciążające: „O, to się zmieniło teraz, mąż (dysponuje dochodem) [...] bo ja się denerwuję, że nam nie wystarczy pieniędzy [...], mnie to bardzo męczyło, w pewnym momencie tak mnie męczyło psychicznie, że ciągle myślałam o pieniądzach i co tu zrobić żeby było ich więcej [...] ciągle się zastanawiam, ile mam pieniędzy na koncie i w ogóle, a teraz to nie wchodzę w ogóle na konto, ale jak wchodziłam, to cały czas się denerwowałam, że... i ciągle takie poczucie, że coś kupiłam i, że nie powinnam tego kupić, bo nam nie wystarcza pieniędzy [...]" (W1).

Planując wydatki, priorytetowe były opłaty stałe: czynsz, opłaty za gaz i prąd (telefon, przejazdówka, rata kredytu) i gdy respondentki wymagały stałego leczenia, do tej grupy należały koszty leków oraz w jednym przypadku papierosy: „Do rachunków się dorzucam, telefon uzupełnić i bilet miesięczny kupić, to jest pierwsza rzecz, no i papierosy, żebym miała zabezpieczenie na cały miesiąc... Ale jak przychodzą jakieś większe zakupy, no to już jest problem, to zazwyczaj się pożycza, to już się robi dziura, buty jakieś czy kurtka, to już jest problem” (W6); „Z ważniejszych rzeczy to są stałe leki, które muszę opłacić, albo jak mi nie starcza, bo tak bywa, że nie starcza, to kombinujemy skąd wziąć pieniędzy na to, wtedy się myśli co można zhandlować, a co nie, i wtedy to już jest taka niepewna sytuacja [...] w tej chwili jajka sprzedajemy, czy trafi mu się robota jakaś to już te pieniążki idą na te łatanie dziur [...] jeżeli zostaje mniej to już wiem, że muszę się zmieścić w tym i tym, moja głowa chodzi na różne sposoby, co gotować, żeby zmieścić się w tej kwocie [..] Nauczyłam się, na cały miesiąc po wypłacie kupuję leki, liczę ile proszków jest w opakowaniu i tyle kupuję, i też wybieram apteki, gdzie jest taniej" (W2).

Jedna $\mathrm{z}$ respondentek wymieniła na pierwszym miejscu nakarmienie dzieci. „Nakarmienie dzieci, czasem były zadłużenia opłaty, ale nakarmienie dzieci było w pierwszej kolejności. Nie mogłam sobie pozwolić na to, żeby dzieci chodziły głodne, więc robienie z niczego coś, to moja specjalność"(W5).

Inny z wywiadów, przeprowadzony z kobietą, która wychowuje pięcioro dzieci, na które przysługuje świadczenie 500+, odróżniał się od innych. Nie widać w nim było zmęczenia respondentki i obciążenia sprawami finansowymi. Nie pojawiały się w nim, charakterystyczne wypowiedzi dotyczące wstydu i upokorzenia w sytuacji biedy. „Wstyd, ale to wcześniej było, dopóki nie mieliśmy tych wszystkich zasiłków. Kiedyś to były takie sytuacje, ale teraz 
jak jest to 500+, to się wszystko pozmieniało" (W3). Można by było uważać, że respondentka po prostu nie żyła w niedostatku, ale średni dochód na osobę nie przekraczał 1000 złotych. Pomimo dużych kosztów leczenia dziecka (wymiana używanych bucików ortopedycznych dla dziecka, to koszt 900 złotych i szyny 1600), nie było to obciążenie nie do uniesienia przez budżet rodziny. W miarę stabilna sytuacja finansowa zależna jest od świadczenia wychowawczego, pozwalającego rodzinie nawet na ponoszenie wydatków związanych

z kosztownym leczeniem. Respondentka zrezygnowała także z korzystania z zasiłku celowego na dożywianie dzieci, ponieważ uważa, że jej sytuacja finansowa jest bardzo dobra.

Wcześniejsze badania biedy, prowadzone przez profesor E. Tarkowską, wskazywały na rodziny wielodzietne jako szczególnie narażone na ubóstwo. Matki wychowujące kilkoro dzieci były także szczególnie zagrożone zjawiskiem feminizacji ubóstwa. Obecnie, można przypuszczać, że zagrożone są rodziny, lub kobiety (szczególnie samotne) mające na utrzymaniu uczące się dzieci, które ukończyły osiemnaście lat i nie przysługuje im świadczenie wychowawcze lub emerytki.

Innym sposobem oszczędności jest planowanie zakupów i korzystanie z promocji. Nie ma tu miejsca na przypadkowość lub uleganie pokusom zakupowym. „Moje zakupy są przemyślane. Idę do sklepu z listą, bo jak tego nie zrobię, to do koszyka trafia tysiąc innych rzeczy, które są potrzebne”(W10); „Ja pracuję w sklepie, to wiem kiedy są promocje, czy przeceny, mam kartę pracowniczą i w czwartki mam 10\% ulgi, to wtedy kupuję(W6) „Zakupy na promocjach, to jest pierwsza, podstawowa rzecz, jeżeli są dobrze wertowane gazetki i szukane okazje, czy kosmetyków, czy środków czystości, czy nawet ubrania, to kupowane jest to na promocji, bo nie stać mnie inaczej" (W10).

Panie planuja posiłki w ten sposób, aby użyte produkty zostały w pełni wykorzystane. Potrafią także gotować „coś z niczego”. „Mąkę mam kupowaną na worki, kartofle mam kupowane na worki, warzywa już nie, bo nie mam gdzie przechowywać, ale jak jesienią dostawało się od kogoś coś, to się to przerabiało i mroziło, eksperymenty były różne. Nauczyłam się, że musi być sparowana i wrzucona na wrzątek, bo inaczej nie da się zjeść, jest niedobra, takich rzeczy się człowiek nauczył” (W5); „Jak była jakaś mąka i cebula, i ktoś jeszcze coś podrzucił, olej jakiś, to kluski z samej mąki i ta cebula smażona, bieda, to już jest skrajna bieda” (W6); „Jak chłopaki dorastały, to ja gotowałam kociołki, jak wpadły to tylko garnki strzelały, mówię z torbami pójdę, to się nadrabiało, coś co treściwsze, ale tańsze" (W7).

Kosztowne potrzeby, np. przyjęcie weselne dzieci, suknia ślubna lub elegantsze ubrania na specjalne okazje, muszą być planowane dużo wcześniej, 
są realizowane z pożyczek, albo dzieci same na nie zarabiają. Sa to potrzeby związane z naturalnym tokiem życia kobiety, która wychodzi za mąż i chce wyglądać pięknie w tym dniu, albo jako dojrzała kobieta wydaje swoje dzieci za mąż. Nawet wtedy kobiety w radykalny sposób potrafią ograniczać wydatki, rezygnując ze swoich marzeń i pragnień. „Sukienkę nie poszłam do salonu kupić, bo taka, która mi się podobała, to kosztowała ze trzy tysiące chyba, tylko znalazłam krawcową i przypomniałam sobie że dostałam sukienkę od kogoś i dało się ją wykorzystać i dokupić trochę materiału i buty to też nie kupowałam nowych tylko te, co miałam i zaproszenia, to też tańszych szukaliśmy. A obrączki, to pierścionek dostaliśmy i obrączkę mojej siostry i u takiego poleconego pana robiliśmy. Nie, do Apartu nie poszliśmy" (W1).

Planowane wydatki nie obejmowały wycieczek szkolnych, wypoczynku czy kultury. „Z wycieczkami to też różnie było, ale mieliśmy dużą pomoc ze szkoły, od rodziców. Jest wycieczka, dziecko by chciało pojechać, ja piszę, że nie pojedzie, bo widzę, że nie pojedzie, jest smutek, rozpacz, a potem pani prosi o wizytę, że rodzice złożyli się na wycieczkę, to było w ten sposób (W2). „Nigdzie nie chodzimy, szkoda pieniędzy, albo nie mamy pieniędzy. Pizza? Mąż w domu zrobi, bo jest taniej” (W1); „Kino, teatr, nie raczej nie, ale nie dlatego że nie było potrzeby, raczej z finansowych [...] ale były organizowane na osiedlu różne festyny, to tam chodziliśmy z dziećmi, to dzieci brały udział i wygrywały różne rzeczy, zabawki jakieś, ale to wiadomo było, bo znali nas wszyscy, to wygrywanie to było takie" (W2).

Oszczędności dotyczyły także edukacji dzieci, dodatkowych zajęć pozalekcyjnych i korepetycji. „Najgorsza jest świadomość tego, że nie stać mnie na korepetycje dla dziewczyn, które są przed maturą i są im niezbędne [..]. Nie stać mnie żeby wysłać je na takie uczelnie, jakie by chciały, jedna chciałaby studiować za granicą, czy w innym mieście, mnie na to nie stać po prostu. Musi zostać w Lublinie” (W10); „Straszny ból i płacz miałam, kiedy nie stać mnie było córce na studia, kiedy ona musiała przerwać te studia, ja o tym spokojnie nie potrafię rozmawiać nawet, tu miałam straszny ból, żal i do dziś nie jestem z tym pogodzona, że nie stać mnie, żeby to dziecko to minimum miało zapewnione, minimum, są rzeczy, które mnie strasznie bolą, że to dziecko miało gorzej” (W2).

Zakup ubrań znajduje się zwykle po wydatkach na żywność, czyli ewentualnie z tego, co zostanie. Nie są to rzeczy niezbędne do przeżycia, więc są ograniczone do minimum, albo pomijane. Najczęściej respondentki kupują potrzebne ubrania w sklepach z „tanią odzieżą̧, często w dniach wyprzedaży po złotówce (tzn. „chodzi się na złotówki”), na przecenach w „normalnych” sklepach lub u „Chińczyka”. Sklepy w Galeriach Handlowych są omijane. 
Panie ich nie odwiedzają, najczęściej nie były w nich ani razu, ponieważ są poza ich finansowym zasięgiem. „Kobieta potrzebuje dużo ubrań, do pracy czy gdzieś, to ja nie kupuję, dostaję raczej od siostry, albo tu od kogoś (W1); „Buty kupuję ewentualnie w „Chińczyku”, ciuchy tam gdzie taniej, a najlepiej w „ciucholandzie” (W4); „Byłam w „ciucholandzie”, patrzę kozaki, ale jest wiosna, odwracam, na podeszwie cztery złote, mam za cztery złote buty na następny rok, lepsze niż te, w których dotąd chodziłam [..] albo w sklepie jak jest przecena, a wiem że mi się przydadzą te buty, to sobie kupię, czerwone to czerwone [...], ale też za dziesięć złotych, i nowe buty za dziesięć złotych kupiłam [...] Takie wyszukiwanie, nieraz chodzę po sklepach, żeby zobaczyć co jest i jak jest [..], więc jak widzę, że naprawdę tanie to kupię, ale mojemu to przestałam mówić takie rzeczy, bo on się denerwuje" (W2).

Osobiste, kobiece potrzeby (kosmetyki, nowe ubranie kupione dla przyjemności, wizyta u fryzjera lub kosmetyczki) są w większości ograniczone do naprawdę niezbędnych (fryzjer, ale nie są to usługi drogie, zwykle proste cięcie). W grupie młodszych respondentek pojawiła się wyraźna świadomość osobistych potrzeb, które muszą być ograniczane, albo w ogóle nie są realizowane: „Kosmetyki to staram się od siostry, żeby mi coś dała, albo kupiła coś taniej, nie, no było, że sobie jakiś tusz kupiłam [...] jak nie mieliśmy pieniędzy a potrzebowałam balsamu, to prosiłam siostrę, żeby mi coś dała, ale cieni jakiś to sobie nie kupuję, raczej dostaję [...]. Fryzjer, to mi było szkoda, szkoda, szkoda, aż w końcu poszłam, ale do kosmetyczki nie chodzę, a wiadomo kobiety chodza do kosmetyczki dwa razy w miesiącu i nie zostawiaja tam dwudziestu złotych” (W1); „Ja nie jestem wymagająca, że bez makijażu nie wyjdziesz z domu, mnie to jakoś nie rusza, ale lubi człowiek też, czy coś się spodoba, klapki jakieś, jakieś spodnie i by zaszalał, a tu czasami dziura w portfelu" (W6).

W większości przypadków respondentki rezygnowały ze swoich potrzeb na rzecz innych członków rodziny. Swoje potrzeby realizowały, gdy wszystkie inne były już zaspokojone: „Najpierw były potrzeby innych, a ja jestem na końcu, tak było całe życie. Nie, nie, ja nigdy sobie nie kupiłam"(W11); „Na pierwszym miejscu zawsze są dzieci. Do zakupów dla mnie zwykle skłania mnie okoliczność. Jak muszę mieć coś nowego kupione na wesele. Ale to jest bardzo, bardzo rzadko" (W10).

Dla respondentek ważna jest zaradność. Respondentki pytane co to jest bieda, cztery z nich określają ją jako niezaradność, w jednym przypadku lenistwo: „Trzeba być zaradnym, zorganizowanym, dbać o czystość i porządek. To wtedy nie będzie, nie będzie taki biedny, nie będzie człowiek z sie- 
bie takiej sieroty robił” (W11); „Człowiek jak jest nauczony od zarania, że trzeba jakoś sobie radzić, do kogo poszłaś na skargę, do kogo?” (W7).

Planowanie w opinii niektórych respondentek jest wyczerpujące i obciążające ich psychikę. „Ja nie konsultowałam tego nigdy z „moim”, jak chodzi o te posiłki, to już było na mojej głowie [..] ale to myślenie to bardzo, bardzo było męczące [...] gdzieś cały czas w głowie to masz [...]. Mam pięćdziesiąt złotych (ośmioro dzieci) i cztery dni do wypłaty, i co ja mogę za to kupić? Mąkę ziemniaczaną mogę kupić, jedziemy na kopytkach półtorej dnia prawie, bo wiadomo kanapki do szkoły muszą być albo też doszłam do wniosku, że taniej mnie wyniesie dzieciom do szkoły na przykład kotlet mielony, niż wędlina, w środek w chleb włożyć [...] To jest kombinowanie, kombinowanie i myślenie na wszystkie strony, nic więcej, planowanie jedna rzecz, a kombinowanie druga. Bo wychodziły też wydatki nie planowane. Dziecko zachorowało, nie ma pieniędzy, skąd było wziąć, trzeba pożyczyć, potem wypłata, trzeba oddać, a oddawanie długów to już było przed opłatami wszelkimi” (W2).

Respondentki są aktywne i zaprzeczają stereotypowemu postrzeganiu osób biednych jako ubogich i roszczeniowych. Żadna z trzynastu respondentek nie ma oszczędności. Badane nie są rozrzutne, ale mały dochód nie wystarcza na odłożenie pieniędzy. Dodatkowe fundusze przeznaczane są na bieżące wydatki, spłatę zadłużeń albo pomoc dzieciom. „Oszczędności? Jak sobie zrobię, a to się nie da”(W4); „Żadnych oszczędności nie miałam, bo zaraz pomoc była rodzinie" (W11).

\section{PODSUMOWANIE}

Z przeprowadzonych badań wyłaniają się fragmenty życia respondentek. Większość z kobiet prowadzi bardzo restrykcyjne oszczędności dotykające wszystkich dziedzin życia. Tylko w przypadku dwóch kobiet strategie ograniczania potrzeb i minimalizacji wydatków nie mają charakteru ciągłego i długotrwałego. Większość kobiet ograniczyła lub zrezygnowała z wydatków na edukację dzieci, kulturę i wypoczynek. Ograniczenia dotykają także potrzeb podstawowych, jak: żywność, opieka medyczna, środki czystości, kosmetyki i odzież. W wywiadach uderza brak roszczeń i stałość podejmowanych działań. Kobiety stale zmagają się z trudną codziennością, nie oczekując od nikogo pomocy, bez wielkich nadziei na poprawę sytuacji. Są skrupulatnymi realizatorkami pomysłów oszczędnościowych, często odziedziczonych po matkach lub babciach. W wywiadach pojawia się świadomość kobiet, że nie 
zawsze mają wpływ na otaczającą je rzeczywistość, a niektóre podejmowane działania są mało efektywne. W literaturze przedmiotu podejmowane działania są klasyfikowane jako pasywne lub umiarkowanie pasywne, jednak w wywiadach uderza codzienna aktywność i ciężka, fizyczna praca wkładana w poszczególne działania (przygotowywanie prostych posiłków, wekowanie, mrożenie). Autorzy badań odeszli od klasyfikowania strategii podejmowanych przez respondentki w kategoriach aktywności i pasywności. Badanie wskazuje na wysoki poziom aktywności i zaangażowania respondentek w podejmowane działania, dlatego nazywanie ich pasywnymi jest nieadekwatne do rzeczywistości.

Działania podejmowane przez respondentki wskazują na duże obciążenie kobiet zarządzaniem dochodem i podejmowanymi działaniami. Takie obciążenie jest elementem feminizacji ubóstwa wskazywanym przez badaczy biedy. Większość respondentek podejmuje wszystkie dostępne działania zmierzające do zwiększenia dochodu i poprawy sytuacji ekonomicznej. Wykorzystuja swoje umiejętności krawieckie i kulinarne. Po przejściu na emeryturę większość z pań jest zmuszona dodatkowo pracować, żeby zabezpieczyć podstawowe potrzeby. Nie mają środków finansowych, ani czasu na dodatkowe aktywności, jak: zajęcia w klubach seniora, uniwersytecie trzeciego wieku, zajęciach gimnastycznych, czy uczestnictwo w kulturze. W badaniach zwraca uwagę poczucie sprawczości kobiet, niezachwiane nieraz małą skutecznością działań. Stała aktywność, zmierzająca do pomnażania zasobów, ograniczona jest jedynie wiekiem lub bardzo poważnym stanem zdrowia.

\section{BIBLIOGRAFIA}

BABBIE E.R., Badania społeczne w praktyce, Warszawa 2003.

Informacja o poziomie minimum socjalnego w 2017 roku, IPiS, Warszawa 2018 (pdf).

JAŚKIEWICZ J., Kobieta-matka w wybranych tekstach publicystycznych Elizy Orzeszkowej, w: Acta Universitatis Lodziensis, Folia Litteraria Polonica, 13, 2010 (pdf).

LISTER R., Bieda, Warszawa 2007.

NASSALSKA E., Ocena instrumentów stosowanych w walce z ubóstwem w opinii ubogich kobiet w Polsce, Wrocław 2011.

TARKOWSKA E., O strategiach radzenia sobie z biedą, w: Ubóstwo, bezrobocie, bezdomność. Działania profilaktyczne, pomocowe, red. M. Mikołajczyk, Warszawa 2015.

TitKow A., Duch-KRZYszToszek D., BUDRowskA B., Nieodpłatna praca kobiet. Mity, realia, perspektywy, Warszawa 2014.

Zwarthoed D., Zrozumieć biedę. John Rawls - Amartya Sen, Warszawa 2012. 


\section{FEMINIZACJA UBÓSTWA I STRATEGIE RADZENIA SOBIE Z BIEDA NA PRZYKŁADZIE MIESZKANEK LUBLINA}

S t r e s z c z e n i e

Feminizacja ubóstwa to nadal temat aktualny i wymagający pogłębionych badań naukowych. Niższy poziom wynagrodzeń kobiet w stosunku do mężczyzn, nieodpłatna i niedoceniana praca $w$ gospodarstwie domowym, wychowywanie dzieci, w konsekwencji niski poziom lub całkowity brak świadczeń emerytalnych, to wszystko powoduje, że kobiety częściej niż mężczyźni są narażone na ubóstwo. Prowadzone przez autorów artykułu badania ukazują dużą aktywność kobiet będących w sytuacji biedy. Większość respondentek wykorzystuje wszystkie dostępne możliwości, zmierzające do minimalizowania wydatków, maksymalizowania przychodów i poprawy sytuacji ekonomicznej rodziny. Z prezentowanych wyników badań wyłania się obraz kobiet aktywnych, zaradnych, które wkładają wiele wysiłku, aby zaspokoić podstawowe potrzeby rodziny. Stoi to w sprzeczności ze stereotypowym postrzeganiem osób biednych jako leniwych, niezaangażowanych we własne sprawy, czekających jedynie na instytucjonalną pomoc.

Słowa kluczowe: ubóstwo; feminizacja ubóstwa; bieda; strategie radzenia sobie z biedą. 